\title{
SUPPLIER-RELATIONSHIP MANAGEMENT, COMPETITIVE ADVANTAGE AND FIRM PERFORMANCE IN THE SERVICE INDUSTRY: A CONCEPTUAL STUDY
}

\author{
Christina Appiah-Nimo, Daniel Ofori, Michael Adu Kwarteng, \\ Miloslava Chovancová
}

\begin{abstract}
This conceptual paper sought to study the relationship among supplier relationship management, competitive advantage and firm performance. The study reviewed literature related to these three variables. Several databases concerning the fields were used to acquire relevant literature on the topic. Methods to conduct future research were also highlighted. The literature reviewed discovered supplier relationship management had a relationship with firm performance although not quite significant but had a stronger influence on competitive advantage. However, competitive advantage appeared most influential as it had a direct relationship with firm performance. Conclusions drawn from the literature are that hotels can improve their performance and survival by having a competitive edge over their competitors. And to achieve this competitive advantage, hotels need to have a collaborative relationship with their suppliers. This conceptual paper ends with recommendations for future research to test whether these variables have any empirical relationships, especially in the hospitality sector.
\end{abstract}

Keywords: Supplier relationship management, competitive advantage, firm performance, hotels

\section{INTRODUCTION}

Today's competitive industries have intensified the challenges associated with getting a product and service to the right place at the right time; without losing out on customers' value and also at reduced costs. Firms have established and integrated effective supply chains to make them more competitive. However, there cannot be an effective Supply Chain Management (SCM) without a conscious relationship with the suppliers. Literature review conducted by Terpend, et al. (2008), found that published papers on buyer-supplier relationships had more than tripled over 20 years. Their study concluded that the focus on the supply side had changed from being a 'buyer practices' to 'buyer-supplier relationship practices'. Moreover, emphasis by Porter (1980) on his five forces model of competitive advantage depicts the importance of building good supplier relationships to achieve competitive advantage. This power of the supplier according to Porter, is the force that explains how easily suppliers can push up the cost of inputs. Thus, the power is affected by the number of suppliers of key inputs of a good or service, how unique these inputs are, and even how much it would cost a company to switch from one supplier to a different one. Additionally, the fewer the number of suppliers, and the more a company depends upon a supplier, the more power a supplier holds to drive up input costs and push for advantage in trade.

However, when a business has many suppliers or the cost of switching between rival suppliers are low, that business can keep input costs at a minimum to increase profit (Porter, 1980). Subsequently, buyers have moved towards long-term, collaborative relationships with fewer suppliers (Cousins et al., 2008). Aside from the growing complexity of technologies, global competition and the need for competitive advantage requires a more collaborative relationship between buyers and suppliers notwithstanding low or high volume suppliers. Hence, it is 
important to involve the supplier at the early stages of need. Supplier Relationship Management (SRM) may be referred to as the practice of planning, organizing, developing, implementing and monitoring of company relationships with current and potential suppliers (Wagner, 2011).

Extant literature proves the role supplier relationship management play in enhancing firm competitiveness and performance is very significant and crucial and therefore needs more research (Kim, 2013; Prajogo et al., 2012; Wook Kim, 2006; Chen, Paulraj \& Lado, 2004; Wisner, 2003; Cousins \& Spekman, 2003; Carter \& Narasimhan, 1996; Ellram \& Carr, 1994). A notable consequence of this enhanced significance of supplier management is that purchasing activities are rarely managed by a single department. This perspective simply means an increased integration and coordination of purchasing and supply management with other departments, including; strategy, marketing, product design, and supply chain management. Hence, Mogre, Lindgreen and Hingley (2017) argued that purchasing in the twenty-first century is evolving into a cross-functional business process.

The service industry has a unique supply chain, in that; it procures both tangible and intangible goods to achieve their core service in business, thus, satisfying their consumers. For instance, when a hotel provides its core service of accommodation, other supporting services come along with such delivery. In addition, most of these support services are provided by suppliers and some by the service provider itself. Generally, customers perceive all services they receive as one and as aiming to provide them the ultimate benefit. Hence, the delivery of a service is not possible without the interplay of many other tangible objects (products) available to both the service provider and the customer. Arguably, a hotel requires furniture and beddings, major appliances, reliable source of water and electricity, fresh foods and many other items to deliver its services to its guests. Practically, guests experience poor services (rude staff, broken beds, unclean sheets, dirty rooms, un-kept wardrobes, poor lightening, no water supply, no hot water supply, electricity power outages, theft, poor or no internet connection, bad meals, broken shower and air-conditions, poor TV channels and noise) by hotels which render them dissatisfied. Issues of poor management are at the top of the list and most of these hotels collapse due to poor patronage. Providing such timely and quality service satisfaction to their guests demands a coordinated and collaborated relationship between hotels and their suppliers. Ultimately, the performance of these hotels highly lies on how well they communicate to get orders delivered or issues sorted by suppliers.

The relationship between supplier management and performance has been empirically examined in different industries including manufacturing (Nimeh, Abdallah \& Sweis, 2018; Hong, Zhang \& Ding, 2018), automotive (Han, Huang \& Macbeth, 2018) and construction (Sindiga, Paul \& Mbura, 2019; Salehi et al., 2018). However, empirical research on the service industry is still lacking and almost non-existent. Due to this, even though, the relationship between the variables can be explained in other industries, many justifications of this relationship cannot rigidly be applied to the service industry. This conceptual study, therefore, sought to bridge the existing knowledge gap by examining the relationship among supplier relationship management, competitive advantage and performance in the hospitality sector in a developing economy.

This conceptual paper has been arranged as follows: the next write-up presents an overview of the theoretical foundation and the conceptual framework followed by the formulation of the research hypotheses. Next is a brief report on the research methods associated with the study. This is followed by the presentation of the significance of the study to theory and practice. This paper concludes with future research directions. 


\section{ANALYSIS AND DISCUSSION OF LITERATURE}

\subsection{Resource-Based View Theory}

The resource-based view theory according to Penrose (1959) is a resource-based (tangible and intangible) perspective for firms to achieve a competitive advantage over other competing firms and also to achieve firm performance. According to Penrose, a firm extends beyond an administrative unit; it is a collection of productive resources, where the choice of different uses of these resources over time is determined. The physical/tangible resources of a firm consist of plant and equipment, land, and natural resources; raw materials; semi-finished goods; waste products and by-products; as well as unsold stocks of finished goods. Additionally, there also exist human resources who possess unskilled and skilled labour including; clerical, administrative, financial, legal, technical, and managerial staff. Penrose further argued that these human resources are not resources in themselves, but rather the services that these resources render forms the basic inputs in the production process.

Thompson (1967) described how the human variable in an organization affected its actions in his book. Hambrick and Mason (1984) later suggested that organizations generally reflect who their top managers are. In addition to these, Finkelstein and Hambrick (1996) also argued how important the human element is in making strategic choice of the firm and its performance. Notably, resources form the basis of firm strategies and are therefore critical to the implementation of those chosen strategies. This study is thus grounded on the Resource-Based View Theory. In the resource-based view theory, strategists can decide on the best form of strategy or competitive position that best exploits the internal resources of the firm (tangible and intangible) and capabilities relative to external opportunities (tangible and intangible).

Arguably, this distinction is the source of uniqueness of each firm. The general purpose of a firm is to organize the use of its resources together with other resources acquired from outside the firm for the production and sale of goods and services at a profit. The supplier thus becomes a very important external resource who can help a firm achieve a competitive edge amongst its rivals and achieve higher firm performance.

\subsection{Supplier relationship management}

Supplier Relationship Management (SRM) according to Wagner (2011) is the practice of planning, organising, developing, implementing and monitoring of company relationships with current and potential suppliers. Suppliers, here, simply refers to an organization that sells inputs to other receiving firms to complete the business. Both suppliers and buyers can stabilize their relationship through discussion and collaborations to manage resources efficiently and effectively. Additionally, suppliers are the indispensable part of the supply chain due to the contribution they make towards increasing product quality, flexibility, and costs (Handfield \& Ragatz, 1999). This is evident in a study by Giannakis, Doran and Chen (2012) who concluded that both parties (supplier and buyer) in the supplier relationship must engage in a long-term relationship and with high commitment levels. To be able to fully exploit the potential of the supply market, a buying firm must establish a good relationship with its suppliers.

\subsection{Competitive Advantage}

Today's competitive pressures compel business leaders to continually seek new sources of sustainable advantage to survive. For instance; Porter's approach to competitive advantage centres on a firm's ability to be a low-cost producer in its industry, or to be unique in its industry with regards to some aspects that are popularly valued by customers (Porter, 1991). Generally, cost and quality remain the competitive advantage dimensions of every firm (D' Souza \& 
Williams, 2000). This implies that competitive advantage no longer resides with a company's innate capabilities but with the relationships and linkages that the firm can forge with external organizations (Lewis, 2000). With the new dynamics of these supply chain partnerships, suppliers and customers are no more treated as though they are independent entities managed in isolation (Spekman, Spear \& Kamauff, 2002). Like any other supply chain literature, this research also posits that establishing and managing effective relationships at every stage in the supply chain is a prerequisite for firm success. Sources of competitive advantage include the ability to leverage purchasing across the entire enterprise while reaping the benefits of supply chain information management.

\subsection{Conceptual framework}

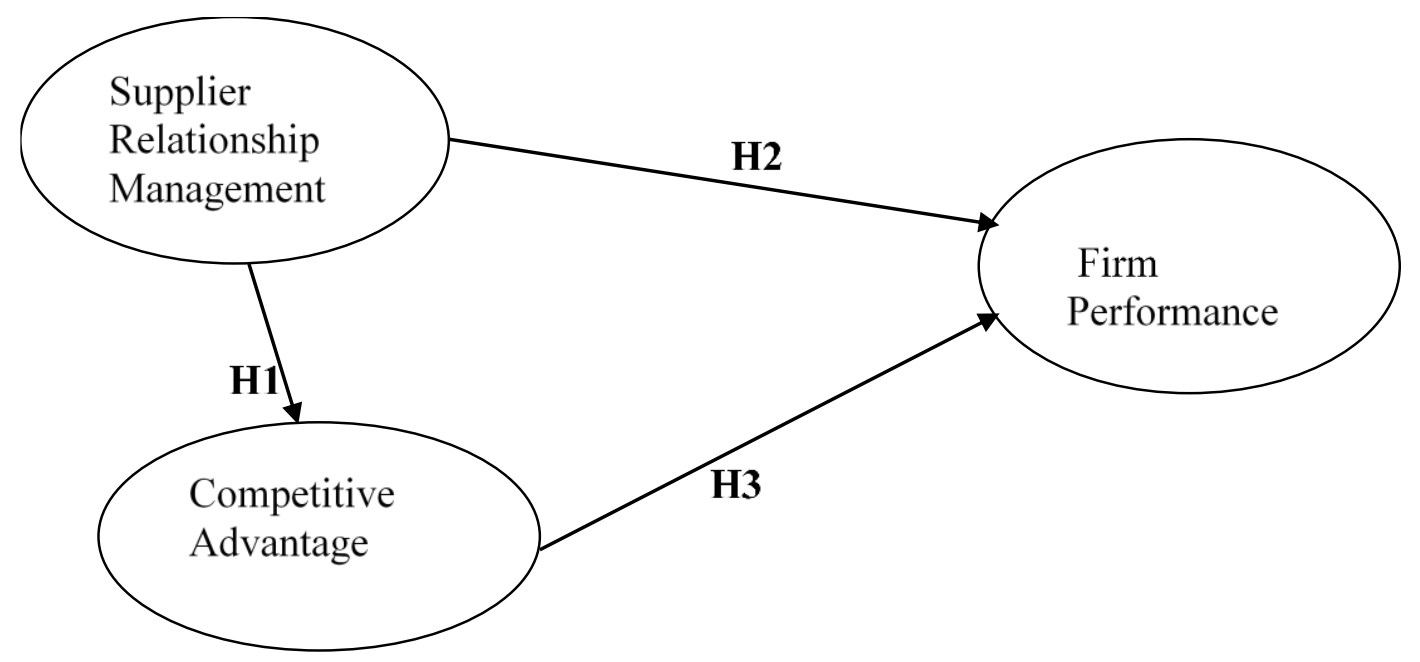

Fig. 1 - Conceptual Framework depicting the hypothesis. Source: own research

\subsection{Supplier Relationship Management, Competitive Advantage and Firm Performance}

Studies on the collaboration between the supplier and the buyer can be reviewed in two ways: by focusing on the collaboration strategy or by using an SRM system to carry out the collaboration strategy. The collaboration strategy can be explored according to the participation phase of new product development and production. In many industries, companies encourage suppliers to be involved in seeking ways to shorten the development time, improve quality, reduce cost, and release new products smoothly. Previous studies have examined the participation time (Handfield \& Nichols, 1999), the responsibility level in cooperative development (Petersen, Handfield \& Ragatz, 2005), and the type and strength of a contractual relationship (Fliess \& Becker, 2006). The most well-known collaboration techniques are JIT purchasing (JITP), which makes the customer's JIT operation possible (Gunasekaran, 1999; Kaynak \& Hartley, 2006); vendor managed inventory (VMI), where suppliers take responsibility for a range of contracts and manage the buyer's inventory (Simchi-Levi et al., 2003); and collaborative planning, forecasting, and replenishment (CPFR), which involves integrating the supply chain.

Finally, studies that have investigated SRM systems for collaboration include system-oriented concepts, such as using an integrative case-based supplier selection method (Choy \& Lee, 2002), a web-based enterprise collaboration platform, and a collaboration framework from the viewpoint of business strategy (Cox et al., 2004; Moeller, Fassnacht \& Klose, 2006). All these studies have found how important SRM is and its influence on firm performance although not directly. Notable amongst them are studies by Yang, Zhang and Xie (2017), Gandhi, Shaikh and Sheorey (2017), Tseng (2014), Al-Abdallah, Abdallah and Hamdan (2014). Collaboration 
with suppliers makes firms more competitive and provides firms with a broader urge over competitors. Hotels aptly and easily adapt to the growing demands of customers and easily design new products or services to suit customers' needs. Their ability to provide quality products and services promptly to attract more customers and increases their overall performance highly depends on suppliers. Meaning, if hotels have a good collaboration and relationship with suppliers, they stand the chance of becoming strong in the industry making them possess enormous competitive advantage over competitors. Therefore, this study hypothesizes that;

H1: Supplier relationship management/supplier management has a positive and significant relationship with competitive advantage.

H2: Supplier relationship management/supplier management has a positive relationship with firm performance.

\subsection{Competitive Advantage and Firm Performance}

The empirical literature has been consistent in identifying price/cost, quality, delivery and flexibility as important competitive capabilities (Koufteros, Vonderembse \& Jayaram, 2005). Besides, other studies have included time-based competition as an important competitive priority. For example studies by Kessler and Chakrabarti (1996) and Zhang and Dhaliwal (2009), identified time as the next source of competitive advantage. Based on prior literature, Koufteros, Vonderembse and Doll (1997) described a research framework for competitive capabilities and defined the following five dimensions: competitive pricing, premium pricing, value-to-customer quality, dependable delivery, and product innovation. Based on these, the dimensions of the competitive advantage constructs used in this study are price/cost, quality, delivery dependability, product innovation, and time to market.

One of the primary objectives of supply chain management is to create greater levels of customer value and competitive advantage for organizations comprising the supply chain. It can be argued that as firms possess higher levels of advantages in the industry, the customer base increases thereby increasing the market share of the firm. Additionally, the expansion in customer base increases the profitability of the firm, thereby, increasing the financial performance of the firm. Constant relationship with suppliers also enables firms to produce quality goods and meets demand on time. Arguably, this increases business or operating performance of firms.

Therefore, this study hypothesizes that;

H3: Competitive advantage has a positive and significant relationship with the performance of firms.

\section{METHODS FOR COLLECTING AND ANALYZING LITERATURE}

This conceptual paper is solely based on reviews and analysis of research and data from related literature. Several methods were used to collect and analyse the literature.

Literature search was conducted using the google scholar search engine. The individual variables were used, though a limited amount of information was found. Literature on supplier relationship management and firm performance proved promising. Other research databases used included Scopus, Web of Science (WOS), ProQuest and EBSCO. All articles deemed relevant to this conceptual paper were retrieved and reviewed. Additionally, books on the topic for this conceptual paper were searched. The same terms used in the database search was used to find books related to the topic. 


\subsection{Data Collection and Data Sources for Future Research}

This conceptual paper is solely based on a review of relevant related literature on the topic of the relationship among supplier relationship management, competitive advantage and firm performance. Future research will be a quantitative study where data will be collected through the administration of questionnaire using valid instruments that measures the variables. Questions for the survey will adopt a Likert scale. The target population would be hotel managers. Issues of ethics will be considered by allowing participants to read and sign a consent form to participate in the study willingly. Participants will also be made aware that information provided in the survey will be completely confidential and used solely for academic purposes.

\section{FINDINGS AND CONCLUSIONS}

The rigorous review of related literature led to the findings about the factors that influence firm performance. SRM was found to have a link to firm performance but not directly but proved to have a strong link to the competitive advantage of the firm. However, competitive advantage had a direct influence on firm performance. The findings were consistent with all other industries. It is evident the long list of factors responsible for firm performance in literature and hotels are no exception to these factors but this paper focused on supplier relationship to achieve competitive advantage, which ultimately affects performance. In conclusion, hotels generally operate on referrals by satisfied customers while considering pricing and location of such hotels. Consumers now constantly receive information and opinions on which hotel gives better satisfaction. To gain acceptance, managers and policymakers of these hotels must access all the factors that impact their performance, particularly how to gain competitive advantage over other hotels. Another conclusion that was drawn from this conceptual paper is that although supplier relationship management has an influence on hotels performance, this relationship is not very strong as it is moderated by competitive advantage. Arguably, competitive advantage has more influence on performance.

\subsection{Theoretical relevance}

This paper discusses the all-important concept of supplier relationship management, competitive advantage and firm performance. It extends the discussion onto one important sector under tourism; hospitality. The paper links the relationships among supplier relationship management, competitive advantage and firm performance. There exists a lot of literature on supplier relationship management and firm performance but none has presented competitive advantage in the discussion. This paper will, therefore, add to literature concerning these variables and providing insights especially in the hospitality sector of Ghana.

\subsection{Managerial relevance}

The ever-increasingly complex environment that hospitality industries find themselves in Ghana is dealing with challenges that threaten their survival and existence. Effective relationship with suppliers in hotels is therefore believed to be a critical requirement for business success. The study, therefore, emphasizes on determining the relationship among supplier management, competitive advantage and firm performance. The relationships were evaluated through rigorous literature review establishing the relationship between supplier management and competitive advantage, supplier management and firm performance and then competitive advantage and firm performance. Extant literature shows that supplier management is an enabler of competitive advantage and both can have a positive relationship with firm performance. This conceptual paper encourages management of hotels and policymakers to 
maintain a balanced relationship and strive to develop and implement collaborative policies that will improve relationships and eventually enhance the performance levels of firms.

\subsection{Limitation and recommendation for future research}

This conceptual paper has its analytic restraints because it relied on data previously collected by other researchers. A second limitation was that all the literature on the topics was not adequately explored due to time constraints. Based on the literature reviewed, it is recommended that further research should be conducted to test whether these variables have any relationships, especially in the hospitality sector.

\section{References}

Al-Abdallah, G. M., Abdallah, A. B., \& Hamdan, K. B. (2014). The impact of supplier relationship management on the competitive performance of manufacturing firms. International Journal of Business and Management, 9(2), 192-202. doi: 10.5539/ijbm.v9n2p192

Carter, J. R., \& Narasimhan, R. (1996). Is purchasing really strategic? International journal of purchasing and materials management,32(4), 20-28. doi: 10.1111/j.1745493X.1996.tb00216.x

Chen, I. J., Paulraj, A., \& Lado, A. A. (2004). Strategic purchasing, supply management, and firm performance. Journal of operations management, 22(5), 505-523. doi: 10.1016/j.jom.2004.06.002

Choy, K. L., \& Lee, W. B. (2002). On the development of a case-based supplier management tool for multi-national manufacturers. Measuring Business Excellence, 6(1), 15-22. doi: $10.1108 / 13683040210420501$

Cousins, P. D., \& Spekman, R. (2003). Strategic supply and the management of inter-and intraorganisational relationships. Journal of Purchasing and supply Management, 9(1), 1929. doi: 10.1016/S1478-4092(02)00036-5

Cousins, P., Lamming, R., Lawson, B., \& Squire, B. (2008). Strategic supply management: principles, theories and practice. London: Pearson Education.

Cox, A., Watson, G., Lonsdale, C., \& Sanderson, J. (2004). Managing appropriately in power regimes: relationship and performance management in 12 supply chain cases. Supply Chain Management, 9(5), 357-371. doi: 10.1108/13598540410560748

D'souza, D. E., \& Williams, F. P. (2000). Appropriateness of the stakeholder approach to measuring manufacturing performance. Journal of Managerial Issues, 12(2), 227-246. Retrieved from https://www.jstor.org/stable/40604306

Ellram, L. M., \& Carr, A. (1994). Strategic purchasing: a history and review of the literature. International Journal of Purchasing and Materials Management, 30(1), 9-19. doi: 10.1111/j.1745-493X.1994.tb00185.x

Finkelstein, S., Hambrick, D., \& Cannella, A. A. (1996). Strategic leadership. St. Paul: West Educational Publishing.

Fliess, S., \& Becker, U. (2006). Supplier integration: Controlling of co-development processes. Industrial Marketing Management,35(1), 28-44. doi: 10.1016/j.indmarman.2005.07.004 
Gandhi, A. V., Shaikh, A., \& Sheorey, P. A. (2017). Impact of supply chain management practices on firm performance: Empirical evidence from a developing country. International Journal of Retail \& Distribution Management, 45(4), 366-384. doi: 10.1108/IJRDM-06-2015-0076

Giannakis, M., Doran, D., \& Chen, S. (2012). The Chinese paradigm of global supplier relationships: Social control, formal interactions and the mediating role of culture. Industrial Marketing Management, 41(5), 831-840. doi: 10.1016/j.indmarman.2012.06.008

Gunasekaran, A. (1999). Agile manufacturing: a framework for research and development. International Journal of Production Economics, 62(1-2), 87-105. doi: 10.1016/S0925-5273(98)00222-9

Hambrick, D. C., \& Mason, P. A. (1984). Upper echelons: The organization as a reflection of its top managers. Academy of Management Review, 9(2), 193-206. doi: 10.5465/amr.1984.4277628

Han, W., Huang, Y., \& Macbeth, D. (2018). Performance measurement of cross-culture supply chain partnership: a case study in the Chinese automotive industry. International Journal of Production Research, 56(7), 2437-2451. doi: 10.1080/00207543.2017.1377357

Handfield, R. B., \& Nichols, E. L. (1999). Introduction to Supply Chain Management. Upper Saddle River: Prentice-Hall.

Handfield, R. B., Ragatz, G. L., Petersen, K. J., \& Monczka, R. M. (1999). Involving suppliers in new product development. California Management Review, 42(1), 59-82. doi: $10.2307 / 41166019$

Hong, J., Zhang, Y., \& Ding, M. (2018). Sustainable supply chain management practices, supply chain dynamic capabilities, and enterprise performance. Journal of Cleaner Production, 172, 3508-3519. doi: 10.1016/j.jclepro.2017.06.093

Kaynak, H., \& Hartley, J. L. (2006). Using replication research for just-in-time purchasing construct development. Journal of Operations Management, 24(6), 868-892. doi: 10.1016/j.jom.2005.11.006

Kessler, E. H., \& Chakrabarti, A. K. (1996). Innovation speed: A conceptual model of context, antecedents, and outcomes. Academy of Management Review, 21(4), 1143-1191. doi: 10.5465/amr.1996.9704071866

Kim, D. Y. (2013). Relationship between supply chain integration and performance. Operations Management Research, 6(1-2), 74-90. doi: 10.1007/s12063013-0079-0

Koufteros, X. A., Vonderembse, M. A., \& Doll, W. J. (1997). Competitive capabilities: measurement and relationships. Proceedings Decision Science Institute, 3(1), 10671068 .

Koufteros, X., Vonderembse, M., \& Jayaram, J. (2005). Internal and external integration for product development: the contingency effects of uncertainty, equivocality, and platform strategy. Decision Sciences, 36(1), 97-133. doi: 10.1111/j.1540-5915.2005.00067.x

Levi, D. S., Kaminsky, P., \& Levi, E. S. (2003). Designing and managing the supply chain: Concepts, strategies, and case studies. New York: McGraw-Hill. 
Lewis, M. A. (2000). Lean production and sustainable competitive advantage. International Journal of Operations \& Production Management, 20(8), 959-978. doi: $10.1108 / 01443570010332971$

Moeller, S., Fassnacht, M., \& Klose, S. (2006). A framework for supplier relationship management (SRM). Journal of Business-to-Business Marketing, 13(4), 69-91. doi: 10.1300/J033v13n04_03

Mogre, R., Lindgreen, A., \& Hingley, M. (2017). Tracing the evolution of purchasing research: future trends and directions for purchasing practices. Journal of Business \& Industrial Marketing, 32(2), 251-257. doi: 10.1108/JBIM-01-2016-0004

Nimeh, H. A., Abdallah, A. B., \& Sweis, R. (2018). Lean supply chain management practices and performance: empirical evidence from manufacturing companies. International Journal of Supply Chain Management,7(1), 1-15. Retrieved from www.researchgate.net/publication/323454401_Lean_Supply_Chain_Management_Pra ctices_and_Performance_Empirical_Evidence_from_Manufacturing_Companies

Penrose, E. (1959). The Theory of the Growth of the Firm. New York: John Wiley and Sons.

Petersen, K. J., Handfield, R. B., \& Ragatz, G. L. (2005). Supplier integration into new product development: coordinating product, process and supply chain design. Journal of Operations Management, 23(3-4), 371-388. doi: 10.1016/j.jom.2004.07.009

Porter, M. E. (1991). Towards a dynamic theory of strategy. Strategic Management Journal, 12(S2), 95-117. doi: 10.1002/smj.4250121008

Porter, M. E. (2008). Competitive strategy: Techniques for analyzing industries and competitors. New York: Simon and Schuster.

Prajogo, D., Chowdhury, M., Yeung, A. C., \& Cheng, T. C. E. (2012). The relationship between supplier management and firm's operational performance: A multi-dimensional perspective. International Journal of Production Economics, 136(1), 120-130. doi: 10.1016/j.ijpe.2011.09.022

Salehi, M., Majbouri Yazdi, H., \& Nekoei, M. (2018). The effect of communication capabilities of suppliers and external green integration on the green and financial performance in Iran. Qualitative Research in Financial Markets, 10(3), 309-323. doi: 10.1108/QRFM11-2017-0100

Sindiga, L. K., Paul, S. N., \& Mbura, L. K. (2019). Influence of procurement management practices on performance of construction firms in Nairobi County, Kenya. International Academic Journal of Procurement and Supply Chain Management, 3(1), 143-163. Retrieved from http://www.iajournals.org/articles/iajpscm_v3_i1_143_163.pdf

Spekman, R. E., Spear, J., \& Kamauff, J. (2002). Supply chain competency: learning as a key component. Supply Chain Management, 7(1), 41-55.doi: 10.1108/13598540210414373

Terpend, R., Tyler, B. B., Krause, D. R., \& Handfield, R. B. (2008). Buyer-supplier relationships: Derived value over two decades. Journal of Supply Chain Management, 44(2), 28-55. doi: 10.1111/j.1745-493X.2008.00053.X

Thompson, J. D. (1967). Organizations in action. New York: McGraw Hill.

Tseng, S. M. (2014). The impact of knowledge management capabilities and supplier relationship management on corporate performance. International Journal of Production Economics, 154, 39-47. doi: 10.1016/j.ijpe.2014.04.009 
Wagner, S. M. (2011). Supplier development and the relationship life-cycle. International Journal of Production Economics, 129(2), 277-283. doi: 10.1016/j.ijpe.2010.10.020

Wisner, J. D. (2003). A structural equation model of supply chain management strategies and firm performance. Journal of Business logistics, 24(1), 1-26. doi: 10.1002/j.21581592.2003.tb00030.x

Wook Kim, S. (2006). Effects of supply chain management practices, integration and competition capability on performance. Supply Chain Management, 11(3), 241-248. doi: $10.1108 / 13598540610662149$

Yang, Z., Zhang, H., \& Xie, E. (2017). Performance feedback and supplier selection: A perspective from the behavioral theory of the firm. Industrial Marketing Management, 63, 105-115. doi: 10.1016/j.indmarman.2016.12.003

Zhang, C., \& Dhaliwal, J. (2009). An investigation of resource-based and institutional theoretic factors in technology adoption for operations and supply chain management. International Journal of Production Economics, 120(1), 252-269. doi: 10.1016/j.ijpe.2008.07.023

\section{Contact information}

\section{Christina Appiah-Nimo}

Tomas Bata University in Zlín, Faculty of Management and Economics

Mostní 5139, 76001, Zlín, Czech Republic

E-mail: appiah_nimo@utb.cz

ORCID: 0000-0001-5597-3553

\section{Daniel Ofori}

University of Cape Coast, School of Business

Cape Coast, Ghana

E-mail: dofori@ucc.edu.gh

ORCID: 0000-0002-7546-6716

\section{Michael Adu Kwarteng, Ph.D.}

Tomas Bata University in Zlín, Faculty of Management and Economics Mostní 5139, 76001, Zlín, Czech Republic

E-mail: kwarteng@utb.cz

ORCID: 0000-0002-6787-0401

\section{doc. Ing. Miloslava Chovancová, CSc.}

Tomas Bata University in Zlín, Faculty of Management and Economics Mostní 5139, 76001, Zlín, Czech Republic

E-mail: chovancova@utb.cz

ORCID: 0000-0002-9244-9563

doi: $10.7441 /$ dokbat.2019.004 